\title{
DNA extraction from Pleistocene bones by a silica-based purification method
}

\author{
Matthias Höss and Svante Pääbo \\ Institute of Zoology, University of Munich, Postfach 202136, D-80021 Munich, Germany
}

Received May 12, 1993; Revised and Accepted July 4, 1993

The polymerase chain reaction has made it possible to include extinct species and past populations in molecular studies of phylogeny and evolution (1). This emerging field, however, is marred by problems, mainly because archaeological remains often yield no amplifiable DNA, extracts often contain components which inhibit the Taq. polymerase, and contamination of trace amounts of contemporary DNA can yield misleading results (2, 3). We have found that the following method, which is a modification of a protocol published by Boom et al. (4), is highly useful in alleviating the former two types of problems and in several cases allows the study of late Pleistocene animal remains that often are not amenable to other extraction procedures.

A layer of approximately $1 \mathrm{~mm}$ is removed from the surface of the bone samples by grinding with a drilling machine in order to reduce contamination from previous handling. The sample is ground to a fine powder under liquid nitrogen in a freezer mill (Spex Industries Inc., Edison, NJ). About $0.5 \mathrm{~g}$ of bone powder is added to $1 \mathrm{ml}$ of extraction buffer consisting of $10 \mathrm{M}$

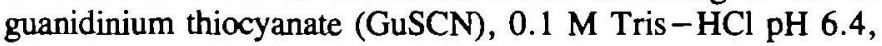
$0.02 \mathrm{M}$ EDTA pH 8.0 and $1.3 \%$ Triton $\mathrm{X}-100$. This is then incubated at $60^{\circ} \mathrm{C}$ for one to several hours with sporadic agitation. After centrifugation for $5 \mathrm{~min}$ at $5,000 \mathrm{rpm}$ about $500 \mu \mathrm{l}$ of the supernatant is recovered and added to a mixture of $500 \mu \mathrm{l}$ of extraction buffer and $40 \mu \mathrm{l}$ silica suspension prepared as in ref. 4. The mixture is incubated for $10 \mathrm{~min}$ at room temperature. Subsequently, the silica pellet is washed twice with a buffer consisting of $10 \mathrm{M} \mathrm{GuSCN}$ and $0.1 \mathrm{M}$ Tris $-\mathrm{HCl}, \mathrm{pH} 6.4$, twice with $70 \%$ ethanol and once with acetone. After drying the pellet at $56^{\circ} \mathrm{C}$, nucleic acids are eluted at $56^{\circ} \mathrm{C}$ in two aliquots of 65 $\mu l$ water or $\mathrm{TE}$ and stored at $-20^{\circ} \mathrm{C}$.

Five $\mu \mathrm{l}$ of the extract are added to a $30 \mu \mathrm{l} \mathrm{PCR}$, in which a wax-mediated hotstart is performed where the upper phase contains BSA, 0.75 units Taq. polymerase (Perkin Elmer, Roche, NJ) as well as the extract. The lower phase contains primers, dNTPs and $\mathrm{MgCl}_{2}$. Both phases are buffered in Tris. The final concentrations after fusion of the phases are: $67 \mathrm{mM}$ Tris $-\mathrm{HCl}$ $\mathrm{pH} 8.8,2 \mathrm{mM} \mathrm{MgCl}, 1 \mathrm{mM}$ dNTPs, and $1.3 \mathrm{mg} / \mathrm{ml}$ BSA. Each of the 40 cycles consists of denaturation at $92^{\circ} \mathrm{C}$ for 40 $\mathrm{s}$, annealing at $55^{\circ} \mathrm{C}$ for $60 \mathrm{~s}$, and extension at $72^{\circ} \mathrm{C}$ for $60 \mathrm{~s}$. After electrophoresis of the PCR products in low-melting agarose gels, bands are cut out and melted in $100 \mu \mathrm{l}$ of $\mathrm{dH}_{2} \mathrm{O}$. Five $\mu \mathrm{l}$ are added to a second $50 \mu \mathrm{l} \mathrm{PCR}$ which is carried out without hotstart and BSA and at $60^{\circ} \mathrm{C}$ annealing. The PCR products are purified using Geneclean (BIO 101 Inc., La Jolla, CA) and sequenced (5). To avoid contamination by contemporaneous DNA, extraction and PCR preparation steps are carried out in a laboratory exclusively dedicated to this purpose. Contamination is monitored by two extraction controls (mock extractions submitted to PCR) per extraction and a PCR control (PCR without extract).

This method allows the extraction of DNA from bone samples of a 25,000-year-old Alaskan member of the horse family, identified as putatively Equus hemionus. Unambiguous direct

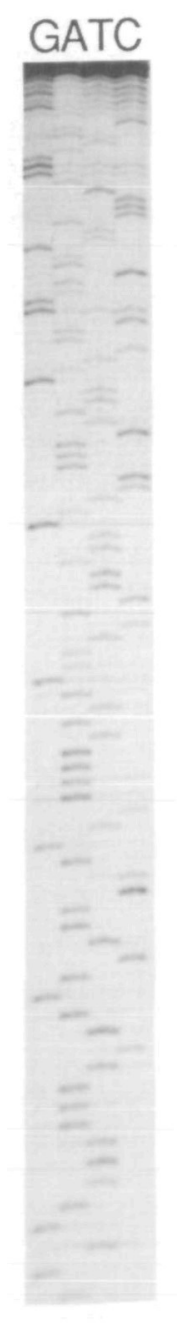

Figure 1. Direct sequencing reaction of amplification product from the mitochondrial 16S rRNA gene of a 25,000-year-old equide. 
3914 Nucleic Acids Research, 1993, Vol. 21, No. 16

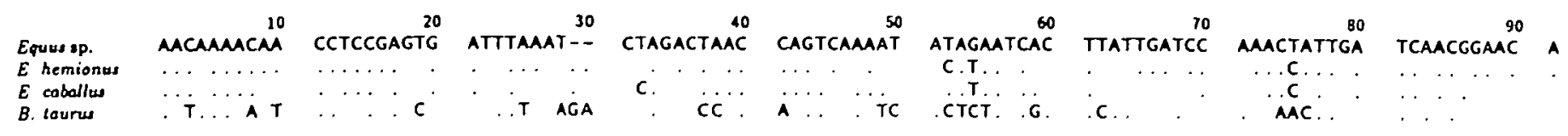

Figure 2. Alignment of a 25,000-year-old putative Equus hemionus, contemporary Equus hemionus (10), horse (Equus caballus) and cow (Bos taurus). Dots represent sequence identity to the ancient sample.

sequence determinations were obtained, e.g. for a $91 \mathrm{bp}$ fragment of the mitochondrial 16S rRNA gene (Figure 1). The sequences show this Pleistocene horse form to be closely related, but not identical, to a contemporary domestic horse, but much further from other ungulates, such as cow (Figure 2). Three other methods for extracting DNA from ancient tissues $(6-8)$ failed in extracting amplifiable DNA from this sample. The same drastic improvement over previously used methods has been achieved also for several bone samples of an extinct ground sloth of late Pleistocene age (Höss et al., in preparation) as well as for mummified remains of Native American populations (Handt et al., in preparation).

It should be noted that due to the DNA-binding capacity of the silica, all buffers, but especially the GuSCN-containing solutions, are very liable to contamination by modern DNA. To overcome this, buffers are prepared in sterile $50 \mathrm{ml}$ tubes and preincubated with silica for several hours in order to bind contaminating nucleic acids. After centrifugation for $3 \mathrm{~min}$ at $3,000 \mathrm{rpm}$, the supernatant is recovered, aliquoted and stored in the dark. It should also be noted that even minimal amounts of silica particles will inhibit the PCR. Thus, to ensure the absence of silica in the extract, it should be centrifuged for $2 \mathrm{~min}$ at 12,000 rpm before removing aliquots for PCR.

This procedure has several advantages for extraction of ancient DNA. Besides its high extraction efficiency, it is simple and fast and therefore allows large numbers of bone samples to be screened in order to identify those that contain surviving DNA molecules. Furthermore, inhibition of the PCR by components of archaeological extracts is abolished. We encountered no example of inhibition in about 50 different bone samples analyzed. In addition, this method has proved very useful for removing inhibitory activities from extracts of other complex sources of DNA, such as animal droppings, which can be of great use for studies of endangered and rare species (9).

\section{ACKNOWLEDGEMENTS}

We thank Prof. Dr H.-P.Uerpmann for bone samples, Oliva Handt for advice and constructive criticism and the DFG (Pa452/1-1) for financial support.

\section{REFERENCES}

1. Pajbo,S., Higuchi,R. and Wilson,A.C. (1989) J. Biol. Chem. 264, $9709-9712$.

2. Sykes,B. (1991) Nature 352, 381.

3. Hős,M., Handt,O. and Pääbo,S. (1993) In, Mullis,K., Gibbs,R. and Ferre,F. (eds), The Polymerase Chain Reaction. Birkhäuser, New York, in press.

4. Boom,R., Sol,C.J.A., Salimans,M.M.M., Jansen,C.L., Wertheim-van Dillen,P.M.E. and van der Noordaa, J. (1990) J. Clin. Micrabiol. 28, $495-503$.

5. Bachmann,B., Lüke,W. and Hunsmann,G. (1990) Nucleic Acids Res. 18, 1309.

6. PAabbo,S. (1990) In, Innis,M.A., Gelfand,D.H., Sninsky,J.J. and White,T.J. (ads), PCR-Protocols and Applications - A Laboratory Manual. Academic Press, San Diego.

7. Persson,P. (1992) Ancient DNA Newsletter 1, 25-27.

8. Walsh,P.S., Metzger,D.A. and Higuchi,R. (1991) BioTechniques 10, 506-513.

9. Hōss,M., Kohn,M., Knnuer,F., Schróder,W. and Päabo,S. (1992) Nature 359, 199.

10. Milinkovitch,M.C., Orti,G. and Meyer,A. (1993) Nature 361, 346-348. 